\title{
Climate change, water resources, and child health
}

\author{
Elizabeth J. Kistin ${ }^{1}$ \\ John Fogarty, MD, MPH ${ }^{2}$ \\ Ryan Shaening Pokrasso ${ }^{3}$ \\ Michael McCally, MD, PhD ${ }^{4}$ \\ Peter G. McCornick, PhD $^{5}$
}

\section{Introduction}

Climate change is occurring and has tremendous consequences for human health. In medical metaphor, the lab reports and vital signs from the earth suggest that our climate is in critical condition. Admitting our planet to the intensive care unit and beginning appropriate treatment will require significant political action at the global scale. In 2009, representatives from governments and organisations around the world gathered in Copenhagen, Denmark for the fifteenth United Nations Climate Change Conference. The goal was laudable: to establish a multilateral agreement to address climate change. However, the results were largely anaemic with countries failing to commit to a binding agreement.

Uncontrolled greenhouse gas emissions will have serious implications on children's health in this century. Leadership from paediatricians and the health care community are critical for initiating and sustaining the kind of global action required for addressing "the biggest global health threat of the $21^{\text {st }}$ century." ${ }^{1}$

\section{Effects of Climate Change}

It is widely acknowledged that human production of greenhouse gases has contributed to both an increase in global temperatures and to the global burden of disease and premature death. ${ }^{2}$ As Table 1 indicates, climate change caused roughly 5.5 million Disability-Adjusted Life Years (DALYs) in $2000 .^{3}$ Continued unmitigated emissions are expected to further threaten human health. Campbell-Lendrum et al (2003) predict that by 2030 unmitigated emissions will result in up to $16 \%$ additional malnutrition, 5\% greater incidence of diarrhoea and $17 \%$ more malaria in Africa (Table 2). ${ }^{4}$ In public health terms, these are enormous increases. Similar though less marked increases are predicted for the South East Asian, Eastern Mediterranean and Western Pacific regions. ${ }^{4}$

Recognizing that the effects of climate change on child health are manifold (Figure 1), ${ }^{6,7,8,9}$ this article focuses on the substantial impacts occurring through changes in water resources. The rise in temperature, precipitation, droughts, floods, glacier melt, and sea levels resulting from human-induced climate change is affecting the quantity, quality, and flow of water resources worldwide and impacting child health through dangerous effects on water supply and sanitation, food production, and human migration.

\footnotetext{
${ }^{1}$ Correspondence to: Nicholas Institute for Environmental Policy Solutions, Duke University, Box 90335, Durham NC, 27708 USA; Elizabeth.Kistin@duke.edu

${ }^{2}$ Department of Family Medicine, University of New Mexico

${ }^{3}$ New Energy Economy, New Mexico

${ }^{4}$ Department of Preventive Medicine, Mount Sinai School of Medicine, New York

${ }^{5}$ Nicholas Institute for Environmental Policy Solutions
} 


\section{Water Supply and Sanitation}

Access to clean water and sanitation are critical to children's health. Malnutrition causes roughly 35 of all deaths of children under the age of five. More than half of these malnutrition deaths are linked to unsafe water, inadequate sanitation, and insufficient hygiene. ${ }^{10}$ Diarrhoea, caused to a large extent by contaminated water, remains the second-leading cause of death in young children, causing over 1.4 million preventable child deaths per year. ${ }^{10}$

Climate change is degrading access to clean water and sanitation, with serious implications for child health. ${ }^{2}$ According to Bates et al. (2008), the combination of population increases, economic growth, demand for more water-intensive food crops, and the regional effects of climate change will result in as much as half of the world's population living in water-scarce river basins by $2050 .{ }^{11}$ Such shortages will be caused, in part, by extended droughts that diminish both the quantity and quality of available water supplies and contribute to deaths, malnutrition, and infectious and respiratory diseases. ${ }^{2}$

In mountainous regions, river systems will also be affected by earlier thawing of snowpack and accelerated glacial melting, resulting in an earlier and increased spring runoff, flooding, and dry-season shortages in the short term. In the medium to long term, severe water shortages are likely in glacierdependent river basins ${ }^{12,13}$ Current predictions suggest that many of the Andes' tropical glaciers will disappear within 20 years, threatening the water supply for over 77 million people living in the region. ${ }^{12}$ In the Himalayas, earlier thawing of the snowpack, accelerated glacial melting, and changes in the characteristics of the precipitation patterns will also impact the quantity and quality of water relied on by billions of people. ${ }^{14}$

In other regions, increases in precipitation, storms, and floods associated with climate change are worsening child health by injury, infectious disease, and toxic contamination (Table 3 ). ${ }^{2}$ Rising temperatures and extreme rainfall are linked to diarrheal diseases in Africa and Asia. ${ }^{15,16}$

Throughout the world, inequities in the distribution and use of water resources have, at times, been a source of tension and dispute. The increase in water scarcity caused, in part, by climate change has the potential to exacerbate existing tensions or spark new disputes related to the allocation and management water resources at the local, national and international level. ${ }^{17}$

\section{Food Production}

Currently, the growth of one-third of all children under five in developing nations (178 million children) is stunted by malnutrition. ${ }^{18}$ For many of these children, access to food will be further threatened as global temperatures continue to rise and key river basins become more susceptible to floods and droughts. "Today for the first time in history," explained Josette Sheeran, Executive Director of the UN World Food Programme, "over a billion people on earth will go to bed hungry and one of the key factors is an increasingly severe and erratic climate." ${ }^{19}$ Nelson et al (2009) anticipate that by 2050 climate change will increase global rates of child malnutrition by $20 \%{ }^{20}$

Declining food production and rising food prices will exacerbate the global rates of malnutrition and stunting and worsen children's health. ${ }^{21}$ In Kenya and Ethiopia, where droughts are common and are expected to become more frequent as temperatures rise, children under six are $36 \%$ and $50 \%$ respectively more likely to experience malnutrition if they are born during a drought. ${ }^{22}$ In Ethiopia, this has resulted in 2 million additional malnourished children in 2005. In Niger, children under three are $72 \%$ more likely to experience stunting if born during a drought. ${ }^{22}$ Stunting and malnutrition are associated with high rates of illness, death, and impaired cognitive development. ${ }^{21}$ 


\section{Migration}

Changes in the quantity and quality, of drinking water as a result of human-induced climate change will also contribute to large increases in human migration. ${ }^{23}$ By 2050 it is expected that roughly 200 million "climate refugees" will be forced from their homelands by events including: increases in the frequency and severity of droughts and natural disasters, sea-level rise, environmental destruction, and diminished access to safe water and food. ${ }^{18}$

The burden of migration due to climate change will fall primarily on the worlds most poor and vulnerable populations with particularly severe consequences for children. ${ }^{24}$ Children are the most susceptible population to vector- and airborne diseases, and are the most impacted by malnutrition. ${ }^{6}$ Exposure to such conditions increases when a population migrates and basic health services become less accessible. ${ }^{6}$

\section{Global Commitments}

Preventing serious deterioration of global child health will require dramatic reductions in greenhouse gas emissions and increases in carbon biosequestration. Scientific agencies and experts have concluded that carbon emissions must be reduced to limit global temperature rise to no more than 2 degrees Celsius above pre-industrial levels. ${ }^{23}$ Based on this evidence, in 2007 the Intergovernmental Panel on Climate Change (IPCC) called on industrialized nations to reduce carbon emissions by $25 \%-40 \%$ below 1990 levels by 2020 and by $80 \%$ by $2050 .^{25}$ Recent reports suggest that these recommendations may be too conservative and that even greater action is needed to avoid a dramatic rise in temperature. ${ }^{26,27}$

Despite high expectations, the Copenhagen Conference failed to produce a binding global treaty. Instead, countries issued the Copenhagen Accord, a statement acknowledging the importance of capping temperature rise at 2 degrees Celsius above pre-industrial levels and encouraging countries to submit their commitments by January 31,2010 . The UK remains dedicated to reducing greenhouse gas emissions by at least $34 \%$ below 1990 levels by 2020 while the EU has pledged $20 \%$ reductions from 1990 levels by the same year. ${ }^{28}$ However, as UK's Energy and Climate Secretary Ed Miliband noted, "there is much further to go, including ensuring we achieve a legally binding outcome for everyone." ${ }^{28}$

\section{Time to Lead}

A significant transformation of our energy economy will be required to avoid extraordinary public-health problems for the children of today and tomorrow. Paediatricians and health care professionals have a critical leadership role to play in motivating and sustaining efforts for policy change and program implementation at the local, national, and international level.

Many paediatric and medical membership organisations in the UK and abroad have already recognized the importance of addressing climate change and have advocated important steps in advocacy, education, research, and personal behaviour. ${ }^{1,29,30,31,32,33}$ The Royal College of Paediatrics and Child Health (RCPCH) has made commitments to reduce its carbon dioxide output by $10 \%$ every year beginning in 2007. The College also facilitated a joint meeting with the BMJ and Faculty of Public Health on addressing climate change within the UK National Health System. ${ }^{34}$

There is a growing body of literature recommending many opportunities for health care professionals and medical organisations to take action on climate change. ${ }^{35,36,37,38,39,40}$ While recognizing the importance of physicians' action at multiple levels and in multiple ways, we must not lose sight of the need for political action at the local, national, and international level. ${ }^{41}$ Combating climate change will 
require more than just turning off the lights. Well-organized medical and public health advocacy is urgently needed.

Paediatricians and physicians can play an important role by putting pressure on professional organisations and societies such as the RCPCH and the European Academy of Paediatrics to adopt climate change as a key advocacy focus area and to dedicate substantial resources for lobbying and political action at the national and international level. Health professionals can join the UK Climate Health Council and the recently launched International Climate Health Council as easy avenues for getting involved political action at multiple scales. In Health Practitioner's Guide to Climate Change: Diagnosis and Cure, Gill and Stott (2009) provide a comprehensive outline of ways in which physicians can act both individually and collectively. ${ }^{41}$

Protection of human health is a core function of societies and governments. Health care professionals have many opportunities to be the vanguard of the global energy transformation and the burgeoning movement to solve climate change. The time to lead is now.

Competing interests: None.

Figures and Tables

Figure 1. Pathways of the impact of climate change on child health

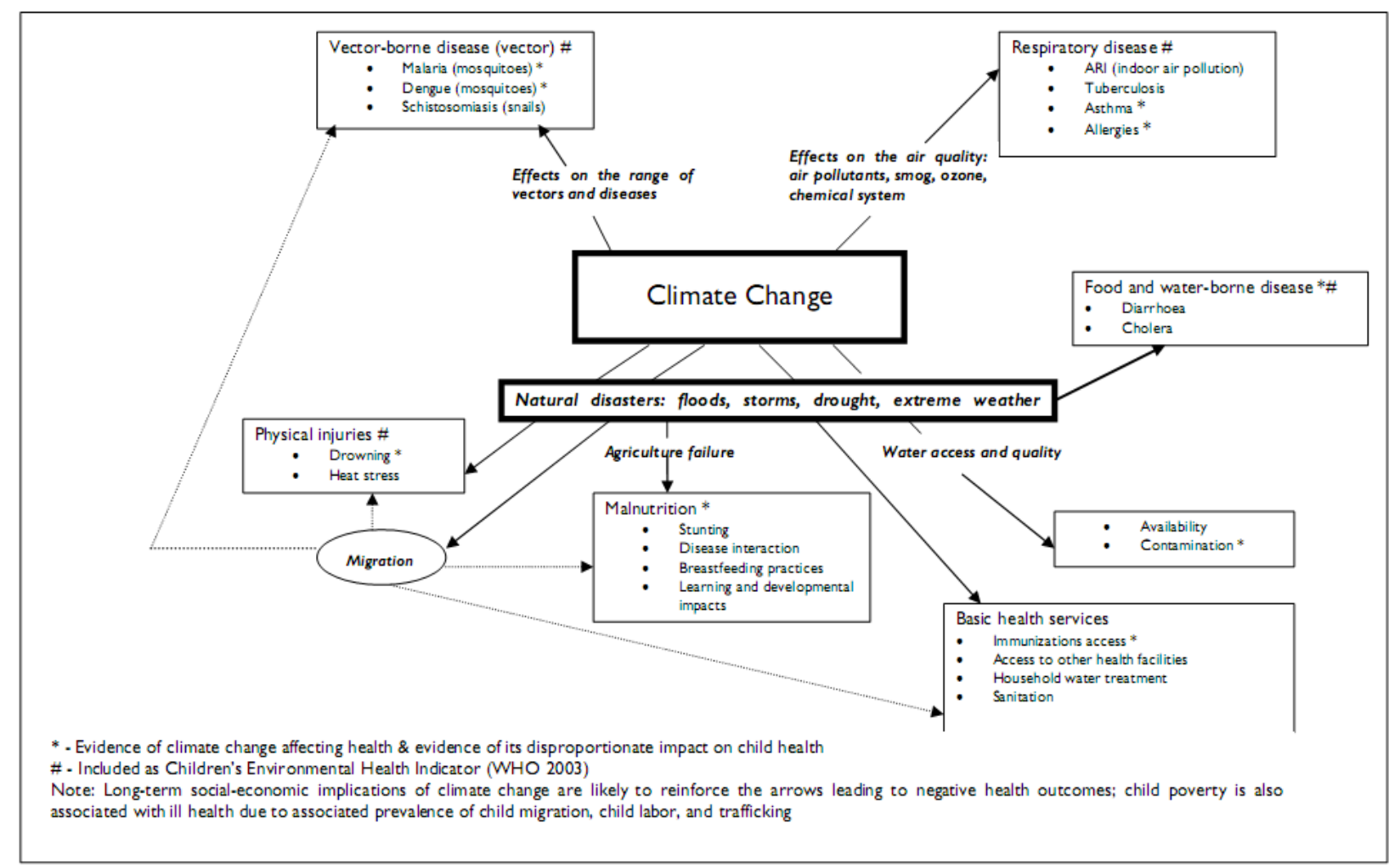

Source: Akachi Y, Goodman D, Parker D. Global climate change and child health: a review of pathways impacts and measures to improve the evidence base. Florence: UNICEF Innocenti Research Center. Available from http://www.unicef.at/fileadmin/medien/pdf/Climatechange_Childhealth.pdf (accessed 14 December 2009).

Table 1. Estimates for the impact of climate change in 2000 (in thousands of DALYs) ${ }^{3}$ 


\begin{tabular}{|c|c|c|c|c|c|c|}
\hline Region & Diarrhoea & Malnutrition & Floods & Malaria & Total & $\begin{array}{l}\text { Total DALYs/ million } \\
\text { population }\end{array}$ \\
\hline African & 414 & 616 & 4 & 860 & 1894 & 3071.5 \\
\hline Eastern Mediterranean & 291 & 313 & 52 & 112 & 768 & 1586.5 \\
\hline $\begin{array}{l}\text { Latin American and } \\
\text { Caribbean }\end{array}$ & 17 & 0 & 72 & 3 & 92 & 188.5 \\
\hline South-East Asian & 640 & 1918 & 14 & 0 & 2572 & 1703.5 \\
\hline Western Pacific $^{1}$ & 89 & 0 & 37 & 43 & 169 & 111.4 \\
\hline Developed Countries ${ }^{2}$ & 0 & 0 & 8 & 0 & 8 & 8.9 \\
\hline World & 1460 & 2847 & 192 & 1018 & 5517 & 920.3 \\
\hline
\end{tabular}

${ }^{1}$ without developed countries.

${ }^{2}$ and Cuba.

Source: McMichael A, et al. Global Climate Change, In: Ezzati M. et al (Eds.), Comparative quantification of health risks: global and regional burden of disease attributable to selected major risk factors, Geneva: WHO, 2004. Available from

http://www.who.int/publications/cra/chapters/volume2/1543-1650.pdf (accessed 14 December 2009)

Table 2. Range of estimates of relative risks attributable to climate change in 2030, under alternative exposure scenarios ${ }^{4}$

\begin{tabular}{|c|c|c|c|c|c|c|}
\hline Region & Climate Scenario & Diarrhoea & Malnutrition & Inland Floods & Coastal floods & Malaria \\
\hline \multirow[t]{2}{*}{ African } & $\begin{array}{l}\text { Unmitigated }^{\mathrm{c}} \\
\text { emissions }\end{array}$ & (0.99-1.16) & $(1.00-1.05)$ & $(1.00-2.27)$ & $(1.20-1.79)$ & $(1.00-1.17)$ \\
\hline & $\begin{array}{l}\text { Rapid emissions } \\
\text { reduction }\end{array}$ & (0.99-1.11) & $(1.00-1.00)$ & $(1.00-3.16)$ & $(1.13-1.55)$ & $(1.00-1.09)$ \\
\hline \multirow[t]{2}{*}{ Eastern Mediterranean } & $\begin{array}{l}\text { Unmitigated } \\
\text { emissions }\end{array}$ & $(0.98-1.16)$ & $(1.00-1.12)$ & $(1.00-6.83)$ & $(2.16-5.61)$ & $(1.00-1.43)$ \\
\hline & $\begin{array}{l}\text { Rapid emissions } \\
\text { reduction }\end{array}$ & $(0.98-1.11)$ & $(1.00-1.06)$ & $(1.00-3.16)$ & $(1.80-1.55)$ & $(1.00-1.09)$ \\
\hline \multirow[t]{2}{*}{$\begin{array}{l}\text { Latin American and } \\
\text { Caribbean }\end{array}$} & $\begin{array}{l}\text { Unmitigated } \\
\text { emissions }\end{array}$ & $(0.92-1.08)$ & $(1.00-1.00)$ & $(1.00-4.24)$ & $(1.80-4.20)$ & $(1.00-1.28)$ \\
\hline & $\begin{array}{l}\text { Rapid emissions } \\
\text { reduction }\end{array}$ & $(0.95-1.05)$ & $(1.00-1.10)$ & $(1.00-3.74)$ & $(1.57-3.28)$ & $(1.00-1.15)$ \\
\hline \multirow[t]{2}{*}{ South-East Asian } & $\begin{array}{l}\text { Unmitigated } \\
\text { emissions }\end{array}$ & $(0.99-1.17)$ & $(1.00-1.27)$ & $(1.00-1.75)$ & $(1.06-1.21)$ & $(1.00-1.02)$ \\
\hline & $\begin{array}{l}\text { Rapid emissions } \\
\text { reduction }\end{array}$ & (0.99-1.12) & $(1.00-1.22)$ & $(1.00-2.49)$ & $(1.04-1.15)$ & $(1.00-1.01)$ \\
\hline \multirow[t]{2}{*}{ Western Pacific $^{a}$} & $\begin{array}{l}\text { Unmitigated } \\
\text { emissions }\end{array}$ & $(0.92-1.09)$ & $(1.00-1.00)$ & $(1.00-3.13)$ & $(1.03-1.10)$ & $(1.00-1.83)$ \\
\hline & $\begin{array}{l}\text { Rapid emissions } \\
\text { reduction }\end{array}$ & $(0.95-1.06)$ & $(1.00-1.02)$ & $(1.00-2.50)$ & $(1.02-1.07)$ & $(1.00-1.43)$ \\
\hline \multirow[t]{2}{*}{ Developed Countries $^{b}$} & $\begin{array}{l}\text { Unmitigated } \\
\text { emissions }\end{array}$ & (0.94-1.06) & $(1.00-1.00)$ & $(1.00-8.79)$ & $(1.32-2.27)$ & $(1.00-1.27)$ \\
\hline & $\begin{array}{l}\text { Rapid emissions } \\
\text { reduction }\end{array}$ & (0.93-1.08) & $(1.00-1.00)$ & $(1.00-7.73)$ & $(1.45-2.81)$ & $(1.00-1.52)$ \\
\hline
\end{tabular}

${ }^{\mathrm{a}}$ without developed countries.

b and Cuba.

"scenario approximately following the IPCC "IS92a" predictions ${ }^{5}$

${ }^{d}$ scenario of rapid emissions reduction resulting in stabilization at 550ppm $\mathrm{CO}_{2}$ equivalent by 2170.

Source: Campbell-Lendrum D, Corvalan C, Pruss-Ustun A. How much disease could climate change cause? In McMichael, A.J. et al (Eds) Climate change and human health : risks and responses, Geneva: WHO, 2003. Available from

http://www.who.int/globalchange/publications/climatechangechap7.pdf (accessed 14 December 2009)

Table 3. Impacts of climate change due to changes in extreme precipitation-related weather ${ }^{11}$

\begin{tabular}{llllll}
\hline $\begin{array}{l}\text { Phenomenon and } \\
\text { Direction of Trend }\end{array}$ & $\begin{array}{l}\text { Likelihood } \\
\text { of future } \\
\text { trends }\end{array}$ & $\begin{array}{l}\text { Agriculture, } \\
\text { Forestry and } \\
\text { Ecosystems }\end{array}$ & Water resources & Human health & $\begin{array}{l}\text { Industry, settlements and } \\
\text { society }\end{array}$ \\
\hline
\end{tabular}




\begin{tabular}{|c|c|c|c|c|c|}
\hline $\begin{array}{l}\text { Heavy precipitation } \\
\text { events: frequency } \\
\text { increases over most } \\
\text { areas }\end{array}$ & Very likely & $\begin{array}{l}\text { Damage to crops; } \\
\text { soil erosion; } \\
\text { inability to cultivate } \\
\text { land due to } \\
\text { waterlogging soils }\end{array}$ & $\begin{array}{l}\text { Adverse effects on } \\
\text { quality of surface } \\
\text { and ground water; } \\
\text { contamination of } \\
\text { water supply; } \\
\text { water scarcity may } \\
\text { be relieved }\end{array}$ & $\begin{array}{l}\text { Increased risk of } \\
\text { deaths, injuries and } \\
\text { infectious, } \\
\text { respiratory and skin } \\
\text { diseases }\end{array}$ & $\begin{array}{l}\text { Disruption of settlements, } \\
\text { commerce, transport and } \\
\text { societies due to flooding; } \\
\text { pressures on urban and } \\
\text { rural infrastructures; loss of } \\
\text { property }\end{array}$ \\
\hline $\begin{array}{l}\text { Area affected by } \\
\text { drought increases }\end{array}$ & Likely & $\begin{array}{l}\text { Land degradation; } \\
\text { lower yields/crop } \\
\text { damage and failure; } \\
\text { increased livestock } \\
\text { deaths; increased } \\
\text { risk of wildfire }\end{array}$ & $\begin{array}{l}\text { More widespread } \\
\text { water stress }\end{array}$ & $\begin{array}{l}\text { Increased risk of food } \\
\text { and water shortage, } \\
\text { malnutrition and } \\
\text { water- and food- } \\
\text { borne diseases }\end{array}$ & $\begin{array}{l}\text { Water shortages for } \\
\text { settlements, industry and } \\
\text { societies; reduced } \\
\text { hydropower generation } \\
\text { potentials; potential for } \\
\text { population migration }\end{array}$ \\
\hline $\begin{array}{l}\text { Intense tropical } \\
\text { cyclone activity } \\
\text { increases }\end{array}$ & Likely & $\begin{array}{l}\text { Damage to crops; } \\
\text { windthrow } \\
\text { (uprooting) of } \\
\text { Trees; damage to } \\
\text { coral reefs }\end{array}$ & $\begin{array}{l}\text { Power outages } \\
\text { causing disruption } \\
\text { of public water } \\
\text { supply }\end{array}$ & $\begin{array}{l}\text { Increased risk of } \\
\text { deaths, injuries, } \\
\text { water-and food- } \\
\text { borne diseases and } \\
\text { post-traumatic stress } \\
\text { disorders }\end{array}$ & $\begin{array}{l}\text { Disruption by flood and high } \\
\text { winds; withdrawal of risk } \\
\text { coverage in vulnerable areas } \\
\text { by private insurers; } \\
\text { potential for population } \\
\text { migrations; loss of property }\end{array}$ \\
\hline
\end{tabular}

Source: Bates BC, Kundzewicz ZW, Wu S, Palutikof JP (Eds). Climate change and water. Technical paper of the Intergovernmental Panel on Climate change. Geneva: IPCC Secretariat, 2008. Available from http://www.ipcc.ch/publications and_data/publications_and_data_technical_papers_climate_change_and_water.htm (accessed 14 December 2009).

\section{References}

1. Costello A, Abbas M, Allen A, et al. Managing the health effects of climate change. Lancet 2009;373:1693-1733.

2. Confalonieri U, Menne B. Human health. Climate Change 2007: Impacts, Adaptation and Vulnerability. Contribution of Working Group II to the fourth Assessment Report of the Intergovernmental Panel on Climate Change, In Parry et al, (Eds.), Cambridge: Cambridge University Press, pp. 391-431.

3. McMichael AJ, Campbell-Lendrum D, Kovats S, et al. Global Climate Change, In: Ezzati M. et al (Eds.), Comparative quantification of health risks: global and regional burden of disease attributable to selected major risk factors, Geneva: WHO, 2004. Available from http://www.who.int/publications/cra/chapters/volume2/1543-1650.pdf (accessed 14 December 2009)

4. Campbell-Lendrum D, Corvalan C, Pruss-Ustun A. How much disease could climate change cause? In McMichael, A.J. et al (Eds) Climate change and human health : risks and responses, Geneva: WHO, 2003. Available from http://www.who.int/globalchange/publications/climatechangechap7.pdf (accessed 14 December 2009)

5. Intergovernmental Panel on Climate Change. Climate change 1995: the science of climate change. Contribution of Working Group I to the Second Assessment Report of the Intergovernmental Panel on Climate Change. Cambridge: Cambridge University Press.

6. Akachi Y, Goodman D, Parker D. Global climate change and child health: a review of pathways impacts and measures to improve the evidence base. Florence: UNICEF Innocenti Research Center. Available from http://www.unicef.at/fileadmin/medien/pdf/Climatechange_Childhealth.pdf (accessed 14 December 2009).

7. Ebi KL, Paulson J. Climate change and children. Paediatric Clinicians of North America 2007;54:213226.

8. Shea KM, Global climate change and children's health. Pediatrics 2007;120(5):1359-67. 
9. Bunyananich S, Landrigan CP, McMichael AJ, Epstein PR. The impact of climate change on child health. Ambulatory Pediatrics 2003;3(1):44-52.

10. Pruss-Ustun A, Bos R, Gore F, Bartram J. Safer water better health: costs benefits and sustainability of interventions to protect and promote health. Geneva: WHO, 2008. Available from http://www.who.int/water sanitation health/publications/safer water/en/index.html (accessed 14 December 2009).

11. Bates BC, Kundzewicz ZW, Wu S, Palutikof JP (Eds). Climate change and water. Technical paper of the Intergovernmental Panel on Climate change. Geneva: IPCC Secretariat, 2008. Available from http://www.ipcc.ch/publications and data/publications and data technical papers climate chang e and water.htm (accessed 14 December 2009).

12. Vergara W, Deeb A, Valencia A, et al. Economic Consequences of Rapid Glacier Retreat in the Andes. Journal of the American Geophysical Union, EOS; 8(25):261-264.

13. Rosenthal E. In Bolivia water and ice tell of climate change. New York Times. Available from http://www.nytimes.com/2009/12/14/science/earth/14bolivia.html? $r=2$ (accessed 14 December 2009).

14. Rai SC. 2005. An Overview of Glaciers, Glacier Retreat and Subsequent Impacts in Nepal, India and China. Kathmandu: WWF-Nepal. Available from http://assets.panda.org/downloads/himalayaglaciersreport2005.pdf (accessed 14 December 2009).

15. Cairncross S, Alvarinho M. The Mozambique floods of 2000: health impacts and response, In Few R, Matthies F (Eds.) Flood Hazards and Health: Responding to Present and Future Risks, 2006; pp.111127.

16. Schwartz BS, Harris JB, Khan Al, et al. Diarrheal epidemics in Dhaka, Bangladesh during three consecutive floods: 1988, 1998 and 2004. American Journal of Tropical Medicine and Hygiene 2006;74:1067-1073.

17. Cooley H, Christian-Smith J, Gleick P, et al. Understanding and reducing the risks of climate change for transboundary waters, 2009. Oakland: Pacific Institute. Available from http://www.pacinst.org/reports/transboundary waters/transboundary water and climate report. pdf (accessed 4 January 2010).

18. Brown LR. Plan B 4.0. New York: WW Norton \& Co; 2009.

19. United Nations World Food Program. Fighting hunger in a changing climate, 2009. Available from http://www.wfp.org/stories/copenhagen-bella-centre-and-virtual-news-conference (accessed 14 December 2009).

20. Nelson GC, Rosegrant MW, Koo J, et al. Climate Change: Impact on Agriculture and Costs of Adaptation. Washington, D.C: International Food Policy Research Institute, 2009. Available from http://www.ifpri.org/publication/climate-change-1 (accessed 14 December 2009).

21. Cohen MJ, Tirado C, Aberman NL, Thompson B. Impact of climate change and bioenergy on nutrition. Rome: FAO and IFPRI, 2008. Available from http://www.fao.org/ag/agn/agns/files/HLC2 Food Safety Bioenergy Climate Change.pdf (accessed 14 December 2009).

22. Watkins K. Human Development Report 2007/2008: Fighting Climate Change-Human solidarity in a divided world. New York: UNDP, 2009, pp. 16-17. Available from http://hdr.undp.org/en/reports/global/hdr2007-2008/ (accessed 14 December 2009). 
23. Stern N. The economics of climate change. Cambridge: Cambridge University Press, 2007.

24. Brown, 0 . Climate change and forced migration: observations, projections and implications. Human Development Report Office, Occasional Paper, 2007. Available from http://www.iisd.org/publications/pub.aspx?id=933 (accessed 14 December 2009).

25. Intergovernmental Panel on Climate Change. Climate Change 2007: Impacts, Adaptation and Vulnerability. Contribution of Working Group II to the Fourth Assessment Report of the Intergovernmental Panel on Climate Change, 2007. Available from http://www.ipcc.ch/index.htm (accessed 14 December 2009).

26. Allison I, Bindoff NL, Bindschadler RA, et al. The Copenhagen Diagnosis, 2009: Updating the World on the Latest Climate Science. Sydney: The University of New South Wales, 2009. Available from http://www.copenhagendiagnosis.org/ (accessed 14 December 2009).

27. Sokolov AP, Stone PH, Forest CE, et al. Probabilistic Forecast for Twenty-First-Century Climate Based on Uncertainties in Emissions (Without Policy) and Climate Parameters. Journal of Climate 2009;22(19): 5175-5204.

28. Department of Energy and Climate Change. Copenhagen Accord to kick start immediate global climate Action. Available from http://www.actoncopenhagen.decc.gov.uk/en/ (accessed 21 December 2009).

29. World Medical Association, Declaration of Delhi on Health and Climate Change, October, 2009. Available from http://www.wma.net/en/30publications/10policies/c5/index.html (accessed 14 December 2009).

30. Royal College of Physicians. Climate Change. Available from http://www.rcplondon.ac.uk/professional-Issues/Public-Health/Pages/Climate-change.aspx (accessed 14 December 2009).

31. American Academy of Pediatrics. Policy Statement: Global climate change and children's health. Pediatrics 2007; 120:1149-52. Available from http://pediatrics.aappublications.org/cgi/content/abstract/peds.2007-2645v1 (accessed 14 December 2009).

32. American College of Preventive Medicine. Climate change-abrupt climate change and public health implications. Available from http://www.acpm.org/2006-002\%28C\%29.htm (accessed 14 December 2009).

33. American Medical Association. Report 3 of the Council on Science and Public Health (CSAPH Report 3-1-08) Global Climate Change and Human Health. Chicago, Illinois: American Medical Association; 2008. Available from http://www.ama-assn.org/ama1/pub/upload/mm/443/csaph3i08-summary.pdf (accessed 14 December 2009).

34. Vickers D, Waterson W. Climate Change and the RCPCH. Lancet 2009;373:2022.

35. MacPherson, CC. Time for Physicians to Take Action on Climate Change. Academic Medicine 2009;84(7):817-818.

36. Griffiths J, Rao M, Adshead F, Thorpe A. The Health Practitioners Guide to Climate Change, Diagnosis and Cure. London: Earthscan, 2009.

37. Stott R, Godlee F. What should we do about climate change? Health professionals need to act now, collectively and individually. BMJ 2006;333:983-984. 
38. Gill M, Godley F, Horton R, et al. Doctors and climate change. BMJ 2007;335:1104-1105.

39. Schwartz BS, Parker C, Glass TA, and Hu H. Global environmental change: What can health care providers and the environmental health community do about it now? Environmental Health Perspectives 2006;114(12):1807-12.

40. Wiley LF, Gostin LO. The international response to climate change: an agenda for global health. JAMA 2009;302(11):1218-1220.

41. Gill $M$ and Stott R. Leadership: How to influence national and international policy, In: Griffiths J, et al (Eds.), The Health Practitioner's Guide to Climate Change, Diagnosis and Cure. London: Earthscan, 2009. 